Open Access

\title{
The effect of service innovation on R\&D activities and government support systems: the moderating role of government support systems in Korea
}

\author{
Si-jeoung Kim ${ }^{1}$, Eun-mi Kim² ${ }^{*}$, Yoonkyo Suh ${ }^{3}$ and ZeKun ZHENG ${ }^{3}$
}

\footnotetext{
* Correspondence: emkim@gstep.re.kr ${ }^{2}$ Gyeonggi Institutes of Science and Technology Promotion, 1

Hyoowon-Ro, Padal-gu, Suwon City, Gyeonggi Province 16444, Republick of KOREA

Full list of author information is available at the end of the article
}

\begin{abstract}
This study analyzes the effects of R\&D activities and government support programs for the product innovation of service industry. With the advent of the knowledge based society, the technology innovation of the service industry has become an important source of national competitiveness. However, the studies on technology innovation have focused on manufacturing industry not the service industry. This study analyzes how differently R\&D activities and the government support programs have influence on product innovation by the size of companies and how the government support programs have a moderate effect in the relationship between the R\&D activities and the innovation.

The results of the study are as follows; first, in case of large enterprises, both the internal and external R\&D activities were proven to be the important elements for product innovation. In case of SMEs, it was analyzed that only the internal R\&D activities are significant. In other words, it was found that internal R\&D activities are the important factors of product innovation for both big companies and SMEs. Second, only the direct financial support for SMEs had a positive effect on product innovation. This can be understood as a result relative to the effectiveness and necessity of direct financial support to SMEs' product innovation. Third, in the case of the moderating effect of the government support programs, the programs that provide indirect opportunity for innovation had the positive moderating effects only for SMEs. In conclusion, internal R\&D activities were proved to be an important factor of product innovation for both large enterprises and SMEs. And government support programs have had a significant effect only in the case of SMEs. To have an impact on the moderated effect of the government support programs for SMEs, the internal R\&D activities were confirmed. This study supports the direction of establishing SMEs support policies in the prospect of service sector innovation.
\end{abstract}

Keywords: Service sector innovation, Service product innovation, Government support programs on innovation, Logistic regression analysis

\section{Introduction}

The role of the service industry in national economies is increasing globally. Following the era of the Industrial Revolution, service industries have been transformed into industrial structures that create high added value. In major overseas economies, such as the

(c) 2016 Kim et al. Open Access This article is distributed under the terms of the Creative Commons Attribution 4.0 International License (http://creativecommons.org/licenses/by/4.0/), which permits unrestricted use, distribution, and reproduction in any medium, provided you give appropriate credit to the original author(s) and the source, provide a link to the Creative Commons license, and indicate if changes were made. 
United States, France, and Japan, the proportion of GDP associated with the service industry is growing. In Korea, the importance of the service industry is also growing, as the share of value-added services has reached up to $58.1 \%$. The proportion of service sector accounts for $70 \%$ even in the employment. Due to this trend, there is increasing social demand and interest in innovation. Indeed, innovation capacity is determining competitive advantage and the survival of companies in the market (Cainelli et al. 2004; Elche and González, 2008; Van Riel et al. 2004; KangKi and Kang 2014).

However, research on innovation has been focused on manufacturing (Brown and Eisenhardt, 1995; Drejer, 2004). This lack of studies on innovation in the service sector is said to be due to endogenous limitations on measuring the quality and performance of services and, in particular, the Korean industrial ecosystem of to accumulate experience of economic growth led by manufacturing.

The impact factor for a company's innovation can be divided into significant internal and external factors. Typical internal factors may be the company's resources and capabilities related to R\&D activities as well as the size of the company. Government support schemes would be an external factor. The role of government in supporting business innovation is very important because technology innovation is one of the significant factors contributing to an increase in national competitiveness.

The purpose of this study is to examine how business R\&D activities and government support programs influence the effects of product innovation, and whether government support programs have a moderating effect on product innovation. This study is meaningful in the following ways. First, it provides a significant contribution to the research on innovation in the service sector, for which there are relatively few studies. Second, it considers how business R\&D activities and government support programs influence product innovation performance. Third, this study analyzes the moderating effect of the government support scheme, which provides implications on how to establish policy geared toward innovation.

\section{Theoretical review and hypothesis}

\section{Characteristics of services innovation}

Innovation-related studies have focused mainly on manufacturing rather than services. A service has characteristics such as aplasia, concurrency, and decaying; thus, it is difficult to distinguish factors affecting service innovation. Considering the limits of the growth of the manufacturing industry and the advent of the knowledge-based service society, this study is focused on service innovation, as industrial and national interest in technology innovation for the service sector has been increasing. Service innovation-related research is approached from two perspectives. First is the demarcation approach, which emphasizes differentiation based on heterogeneous factors. Second is the assimilation approach, which is based on the premise that there is no difference between the innovation system of the manufacturing and service industries. Recently, a comprehensive integrated approach has arisen, but is still in its rudimentary stage. Moreover, the issue of heterogeneity and similarities between technology innovation in the manufacturing and service industries needs to be demonstrated consistently (Kim, 2010).

An assimilation approach is based on the perspective that the service industry achieves innovation by introducing new technologies and new processes from other 
industries because technology innovation and productivity improvements are minimal in the service sector itself. Further, this approach has a profound relationship with the subordinate survey, one of the approaches used to investigate innovation in the service sector (Djellal and Gallou 2000, 1999; Lee et al., 2013). The subordinate survey means that the same method used to research innovation in the manufacturing industry is applicable to the service sector. This approach is used in the Community Innovation Survey (CIS) and the Korean Innovation Survey (KIS), for example. Many innovationrelated studies have been carried out based on the data of the KIS using assimilation approaches. Based on the discussion so far, innovation performance in the service sector can be divided into product innovation and process innovation, as has been done for manufacturing innovation studies (OECD, 2005). There is no definite conclusion on which is reflected more heavily in the results regarding service sector innovation. Numerous theoretical reviews, including Hipp and Grupp (2005),showed prominent performance for product innovation in both the service and manufacturing sectors, but the results for process innovation are relatively few. Therefore, this study sets product innovation as the dependent variable, as it has a more noticeable result than process innovation does.

\section{The relationship between open innovation and its performance}

Traditionally, research and development (R\&D) activities in the terms of Open Innovation have been considered as important inputs for innovation (Romer, 1990; Geroski, 1994; Dinopoulos and Thompson, 1998). Manufacturers have focused on new technologies and new product development through technology innovation and services have enhanced the innovation capacity of companies through innovation in management (Howells and Tether 2004). However, recently, there has been increasing awareness of the potential for 'non-technical' innovation in the manufacturing sector to strengthen manufacturing competitiveness. Moreover, technical innovation is highly valued for the promotion of services. R\&D expenditures in the service sector are constantly increasing, and the service enterprise is aiming to improve product development and the production process by increasing both internal and external R\&D activities (Edwards and Croker, 2001). In particular, the R\&D activities of service companies are more relevant to product innovation than to process innovation, and process innovation has been closely related to external factors (Rouvinen 2002).

In terms of Open Innovation, companies which perform R\&D activities combine inhouse research, expertise, and capabilities with external knowledge, expertise to accelerate innovation in product and technology development of the firm. Companies perform the R\&D activities based on the Open Innovation model. The Study shows that service $R \& D$ activities include internal $R \& D$, cooperate $R \& D$, and external $R \& D$ regarding Open Innovation (Swapan Kumar and Krishna 2015; Fumio \& Shibata 2015).

\section{The relationship between firm size and innovation performance}

The representative study for the relationship between firm scale and technical innovation is that of Schumpeter(1942). It hypothesizes that the larger an enterprises is, the more lively its innovation activities. According to economy of scale, larger companies are more active in innovation activities and more likely to commercialize new 
technology. Since Schumpeter's hypothesis was raised, various empirical analyses about the relationship between firm size and R\&D have been carried out, and a wide range of results are still being discussed today. According to Scherer and Ross (1990), R\&D efficiency can drop as a company's scale increases, as large enterprises have lax management and scientists' and engineers' motives to invent can be lost to bureaucracy. On the other hand, Cohen (1995), Cohen and Klepper (1996), and others showed that there is a positive relationship between firm size and technology innovation. Scherer (1965) demonstrated that there is an inverted $U$-shaped relationship between firm size in certain industries and technology innovation. These studies indicate that in all industrial areas, a firm's size must be at a particular threshold in order to be effective in carrying out innovation activities. Thus, it seems that firm size has a significant impact on innovation performance (Cohen, 1995; Rogers, 2004; JinHyo Joseph 2015). Company size should be considered in light of the present domestic business ecosystem, as empirical research on Korea provides similar results (Sung 2003). As stated above, R\&D activities are seen as an important input factor for service innovation performance. Hypothesis 1 verifies the relationship between $R \& D$ activities, as independent variables, and technological innovation. It reaffirms previous research results showing that R\&D activities in the service sector have a close relationship with product innovation performance based on empirical analysis.

$<$ Hypothesis $1>$ The type of R\&D activities affecting product innovation in the service sector will vary depending on firmsize.

$<1-1>$ The R\&D activities of large-sized companies affect product innovation in the service sector.

$<1-2>$ The R\&D activities of SMEs affect product innovation in the service sector.

The relationship between government support programs and innovation performance

Previous studies mainly considered the various government support programs as external factors of enterprise technology innovation. Cerulli \& Poti (2008) found that there is a positive relationship between government support schemes and business sales by doing empirical research on the Italian Innovation Survey Data. Czarnitzki \& Hussinger (2004) also indicated that the government support schemes have led to the productivity improvement because increased number of patents have played a great role as an important output factor in the innovation performance. Korean researchers, likewise, have suggested the possibility of enforcing the government support systems in the field of innovation performance of companies (Jongkook and Hyukjoon 2009; Hongrim and Sungjun 2006; Ryu \& Choi, 2011). Government support schemes are classified by researchers using a variety of criteria, such as in (Table 1). In particular, Lee's (2011) study on the Korean Innovation Support System showed that innovation support programs can be classified as supports for tax incentives, finance, technology development, human resources, purchasing, law and institutional infrastructure, or other indirect supports based on the expenditure approach. In Korea, government innovation support systems are considered an important factor in innovation performance. Indeed, the Korea business ecosystem offers many successful examples of government-led industrial development. 
Table 1 Government Support Program

\begin{tabular}{ll}
\hline Persons & Types and tools \\
\hline Hood (1986) & Authority, Nodality, Treasure, Formal Organization \\
McDonnell and Elmore (1987) & Mandates, Inducements, Capacity Building, System Changing \\
Schneider and Ingram (1990) & Authority tool, Capacity tool, Symbolic tool, Learning tool \\
Keizer et al. (2002), Shefer and Frenkel (1998), & Finance, Human Resources \\
Lin et al. (2006), Hall and Bagchi-sen (2002) & \\
Vedung (2005) & Sticks, Carrots, Sermon \\
KIM\&DO (2004) & $\begin{array}{l}\text { direct support and indirect support, financial benefit } \\
\text { and non financial benefit }\end{array}$ \\
KIM (2014) & Financial support, direct support, indirect support \\
\hline
\end{tabular}

When classifying the innovation support programs of a government, a subsequent commercialization stage should be considered as well as the promotion of technology innovation. This perspective applies equally to the case of Korean innovation support programs. Kim (2014) classified the Korean government's innovation support programs into direct and direct supports and financial benefits and non-financial benefits. Kim (2014) classified direct support as financial supports, R\&D, and R\&D education supports; and indirect support as technology information, human resources supports, and public procurement.

Based on the discussion above, this study divided various government support programs affecting service innovation into three types. First, financial support, such as tax reduction and commercialization funding is a major factor that influences the introduction of technologies and $R \& D$. It has characteristics as a tool to induce technology innovation and subsidize companies' technology innovation activities. Second, programs to support innovation opportunities include support for R\&D, technology information, human resources, and education. Third, programs to diffuse the results of innovation include programs for marketing and public procurement.

Hypothesis 2 of this study analyzes the relationship between government support programs, as independent variables, and product innovation in the service sector, as dependent variables.

$<$ Hypothesis 2> The type of government support programs affecting product innovation in the service sector will vary based on firm size.

$<2-1>$ Large-sized companies that have gained a benefit from government support will affect product innovation in the service sector.

$<2-2>$ SMEs that have gained a benefit from government support will affect product innovation in the service sector.

In relation to the factors affecting technical innovation, R\&D activities are considered an internal impact factor, and government support programs are considered an external impact factor. However, there are a very few number of studies concerning the linkage between the government support programs and R\&D activities that led to a positive influence in the innovation performance. In contrast, there are relatively a more number of researches on the relationship between government financial support systems and companies' innovation performance or between the government support system and business R\&D activities. Therefore, the question whether the government financial support system 
has a moderating effect on the relationship performance in the service sector needs to be confirmed and analyzed further. Some preceding research has presented results of the moderating effect of government support programs on the relationship between enterprises' R\&D activities and product innovation performance (Kang, 2013). However, such studies have typically targeted the manufacturing industry, not the services sector. Given that the government has recently expanded its support for SMEs in the service sector, this study empirically analyzes the moderating effect of government support programs on the relationship between companies' R\&D activities and product innovation performance in the service sector. The effect of firm size is also investigated. The results are expected to offer meaningful implications on the establishment of policy to support service sector innovation.

$<$ Hypothesis $3>$ When enterprises take advantage of the government's innovation support system, the effect of product innovation will be strengthened.

$<3-1>$ When large-sized companies take advantage of the government's innovation support system, the effect of product innovation will be strengthened.

$<3-2>$ When SMEs take advantage of the government's innovation support system, the effect of product innovation will be strengthened.

\section{Survey design}

\section{Data and research method}

This study utilizes data from the Korea Innovation Survey (KIS) 2012: Service Sector. The population includes service providers with more than 10 regular employees that were active from 2009 to 2011 (service companies less than $45-96$ by Korean Standard Industrial Classification (KSIC)). This survey targeted a total of 54,831 companies. The responses of 4063 companies were made available by multistage stratified and systematic sampling. For the present study, 615 samples were extracted by eliminating missing values (null) of major variables.

\section{Variables}

\section{Dependent variables}

Product innovation in the service sector, the dependent variable, consisted of two items: to release new items completely different from existing products and to significantly enhance products. If at least one of the dichotomous outcomes was yes, it was regarded as valid innovation $(\mathrm{Y}=1)$; if both responses were no, it was regarded as invalid innovation $(\mathrm{Y}=0)$, such as in (Table 2).

\section{Independent variables}

The R\&D activities of companies, the independent variable, were classified into three items: internal R\&D activities (X1), joint R\&D activities (X2), and external R\&D activities (X3). The responses were checked for these three items, such as in (Table 2).

\section{Moderator variable}

Government support programs, the moderator variable, are composed of three items: 1 ) direct financial supports (M1), 2) indirect support to provide opportunity for innovation (M2), and 3) indirect support to diffuse the result of innovation (M3). Nine interaction 
terms related to R\&D activities and government support system (X1*M1, X2*M1, $\left.\mathrm{X} 3{ }^{*} \mathrm{M} 1 / \mathrm{X} 1 * \mathrm{M} 2, \mathrm{X} 2{ }^{*} \mathrm{M} 2, \mathrm{X} 3{ }^{*} \mathrm{M} 2 / \mathrm{X} 1{ }^{*} \mathrm{M} 3, \mathrm{X} 2{ }^{*} \mathrm{M} 3, \mathrm{X} 3 * \mathrm{M} 3\right)$ were created to analyze the moderating effects. The result of the variance inflation factor (VIF) among independent variables used as an interaction predictor was less than 10, which means that multicollinearity did not arise (Neter et al., 1985). Thus, the process of mean-centering was omitted, such as in (Table 2).

\section{Control variable}

Workforce size dedicated to $R \& D$ was adopted as a control variable. Major preceding research utilized workforce size dedicated to R\&D for an indicator showing companies' activity.

\section{Research model}

The study was carried out using binary logistic regression. This statistical analysis technique can be used when the dependent variable is binary and nominal (Aldrich and Nelson 1986; Hur). If observations are independent, a nonlinear regression model can be employed, which is relatively easy to use compared to linear regression analysis. Moderated regression analysis (MRA) was used to verify the effect of the control variables. Each logistic regression equation is as follows:

$$
\begin{aligned}
& \ln \left(\frac{P(Y 1)}{1-P(Y 1)}\right)=\beta_{0}+\beta_{1} X_{n}+\beta_{2} M_{n}+\beta_{3} C \\
& \ln \left(\frac{P(Y 1)}{1-P(Y 1)}\right)=\beta_{0}+\beta_{1} X_{n}+\beta_{2} M_{n}+\beta_{2} M_{n}+\beta_{3} X_{n} M_{n}+\beta_{4} C
\end{aligned}
$$

Y Product innovation performance, $\mathrm{P}(\mathrm{Y})=$ Probability of product innovation $\mathrm{X} 1$ Internal R\&D, $\mathrm{X} 2=\mathrm{Co} R \& D, X 3=$ External $R \& D$

M1 Direct financial support, M2 = Indirectly providing opportunities for innovation, M3 = Indirectly diffusing of innovation performances

C R\&D workforce size

\begin{tabular}{|c|c|c|c|c|}
\hline Variables & & & & Variable measurement \\
\hline \multirow{3}{*}{$\begin{array}{l}\text { Dependent } \\
\text { variables }\end{array}$} & \multirow[t]{3}{*}{ R\&D activity } & Internal R\&D & $\mathrm{X}_{1}$ & \multirow{3}{*}{$\begin{array}{l}\text { Whether companies have carried out } \\
\text { R\&D activities from } 2009 \text { to } 2011 \text {. }\end{array}$} \\
\hline & & Cooperate R\&D & $\times 2$ & \\
\hline & & External R\&D & $\times 3$ & \\
\hline $\begin{array}{l}\text { Independent } \\
\text { variables }\end{array}$ & $\begin{array}{l}\text { Product innovation } \\
\text { performance }\end{array}$ & $\begin{array}{l}\text { Achieving product } \\
\text { innovation performance }\end{array}$ & Y & $\begin{array}{l}\text { Whether companies have achieved } \\
\text { product innovation performance } \\
\text { from } 2009 \text { to } 2011 \text {. }\end{array}$ \\
\hline \multirow[t]{3}{*}{$\begin{array}{l}\text { Moderator } \\
\text { variable }\end{array}$} & $\begin{array}{l}\text { Government } \\
\text { support }\end{array}$ & Direct financial support & M1 & $\begin{array}{l}\text { Whether companies have received } \\
\text { government's finance supports including } \\
\text { tax reduction from } 2009 \text { to } 2011 \text {. }\end{array}$ \\
\hline & \multirow[t]{2}{*}{ Program } & $\begin{array}{l}\text { Indirectly providing } \\
\text { innovation opportunity }\end{array}$ & $\mathrm{M} 2$ & $\begin{array}{l}\text { Whether companies have received } \\
\text { government's indirect support to } \\
\text { provide opportunity innovation } \\
\text { from } 2009 \text { to } 2011 .\end{array}$ \\
\hline & & $\begin{array}{l}\text { Indirectly support for } \\
\text { diffusing the results of } \\
\text { innovation }\end{array}$ & M3 & $\begin{array}{l}\text { Whether companies have received } \\
\text { government's support programs } \\
\text { for marketing and public } \\
\text { procurement from } 2009 \text { to } 2011 \text {. }\end{array}$ \\
\hline $\begin{array}{l}\text { Control } \\
\text { variable }\end{array}$ & R\&D workforce size & & C & Size of R\&D workforce in 2011 \\
\hline
\end{tabular}

Table 2 Definition of Variables 


\section{Results}

\section{Descriptive statistics}

Table 3 represents a descriptive statistical analysis. The sample was classified into largescale companies and SMEs according to legal standards. There were a total of 74 large-sized companies (12\%) and 541 SMEs (88 \%).

\section{Hypothesis testing results}

\section{Model compliance verification}

The significance of the model was verified through the likelihood ratio test. This allowed consideration of the conformity of the research model, which analyzes $R \& D$ activities affecting service product innovation. First, the chi-squared statistic for the large firms is 26.973, and is valid at the level of $p<.01$ As a result of Hosmer-Lemeshow verification, the valid probability is found to be 0.539 . Thus, the model is deemed suitable, with $74.3 \%$ prediction accuracy based on the criteria table. Second, the chi-squared statistic for the SMEs is 28.594, and is valid at the level of $p<.01$ The result of the Hosmer-Lemeshow verification is 0.936 of valid probability. Therefore, the model is confirmed to be suitable, with $60.8 \%$ prediction accuracy.

\section{Hypothesis testing}

Table 4 presents the analysis of the results regarding the impacts on service-product innovation performance when large firms and SMEs conduct R\&D using government support programs. And Table 4 also includes the results of the analysis of the moderating variable on the impact of companies' $R \& D$ activities for product innovation performance.

(1) R\&D Activities and Government Support Programs' Impact on Service-Product Innovation Performance (Hypothesis 1, Hypothesis 2)

First, in the case of large firms, internal $R \& D$ activities are valid at the level of $p<.01$, and external R\&D activities are valid at the level of $p<.05$ based on the result of Wald

Table 3 Descriptive statistics

\begin{tabular}{|c|c|c|c|c|c|c|c|c|}
\hline \multirow[t]{2}{*}{ Variables } & \multicolumn{4}{|c|}{ Large firm (observations = 74) } & \multicolumn{4}{|c|}{ SEM ((observations = 541) } \\
\hline & Min. & Max & mean & SE & Min. & Max & mean & SE \\
\hline$\overline{x 1}$ & 0 & 1 & .65 & .481 & 0 & 1 & .42 & .495 \\
\hline$x 2$ & 0 & 1 & .36 & .485 & 0 & 1 & .15 & .355 \\
\hline$x_{3}$ & 0 & 1 & .20 & .405 & 0 & 1 & .11 & .307 \\
\hline M1 & 0 & 1 & .2838 & .45391 & 0 & 1 & .3530 & .47836 \\
\hline M2 & 0 & 1 & .2703 & .44713 & 0 & 1 & .2015 & .40148 \\
\hline M3 & 0 & 1 & .1622 & .37112 & 0 & 1 & .0739 & .26191 \\
\hline Y1 & 0 & 1 & .5811 & .49675 & 0 & 1 & .5342 & .49929 \\
\hline C & 0 & 99999 & 1385.54 & 11620.9 & 0 & 273 & 5.28 & 21.643 \\
\hline
\end{tabular}


Table 4 Logistic Regression Analysis

\begin{tabular}{|c|c|c|c|c|c|c|c|c|}
\hline \multirow[t]{2}{*}{ Variables } & \multicolumn{2}{|l|}{ Model 1} & \multicolumn{2}{|l|}{ Model2 (M1) } & \multicolumn{2}{|l|}{ Model3 (M2) } & \multicolumn{2}{|l|}{ Model4 (M3) } \\
\hline & Large firm & SME & Large firm & SME & Large firm & SME & Large firm & SME \\
\hline $\mathrm{X} 1$ & $2.093^{* * *}(8.106)$ & $.667^{* * *}(1.948)$ & $2.398^{* * *}(10.997)$ & $.459 * *(1.582)$ & $2.327^{* * *}(10.245)$ & $.375 *(1.455)$ & $1.797^{* * *}(6.030)$ & $.409^{* *}(1.506)$ \\
\hline$\times 2$ & $-.439(.645)$ & $.357(1.429)$ & $.239(1.270)$ & $.153(1.165)$ & $-.011(.989$ & $-.038(.962$ & $-.292(.747)$ & $.229(1.257)$ \\
\hline X3 & $2.643^{* *}(14.052)$ & $-.085(.918)$ & $1.983(7.262)$ & $-.054(.948)$ & $1.823(6.189)$ & $.053(.898)$ & $2.159^{*}(8.662)$ & $-.365(.694)$ \\
\hline M1 & $-.179(.836)$ & $.657^{* * *}(1.930)$ & $.900(2.460)$ & $.469^{* *}(1.598)$ & & & & \\
\hline M2 & $-.911(.402)$ & $-.807^{* * * *}(.446)$ & & & $.781(2.184)$ & $-1.516^{* *}(.220$ & & \\
\hline M3 & $.274(1315)$ & $.419(1.520)$ & & & & & $-19.131(.000)$ & $-.485(.411)$ \\
\hline C & $.004(1.004)$ & $.002(1.002)$ & $.003(1.003)$ & $.001(1.001)$ & $.005(1.005)$ & $.002(.1 .002)$ & $.002(1.002)$ & $.000(.936)$ \\
\hline $\mathrm{X} 1 * \mathrm{M} 1$ & & & $-1.386(.250)$ & $.234(1.264)$ & & & & \\
\hline $\mathrm{X} 2 * \mathrm{M} 1$ & & & $-1.771(.170)$ & $.215(1.24)$ & & & & \\
\hline $\mathrm{X} 3 * \mathrm{M} 1$ & & & 19.829(409037997) & $-.271(.762)$ & & & & \\
\hline $\mathrm{X} 1 * \mathrm{M} 2$ & & & & & $-2.167(.115)$ & $1.207^{* *}(3.342$ & & \\
\hline $\mathrm{X} 2 * \mathrm{M} 2$ & & & & & $-.740(.477$ & $.992(2.696$ & & \\
\hline $\mathrm{X} 3{ }^{*} \mathrm{M} 2$ & & & & & $20.100(536195041)$ & $-.54(.583)$ & & \\
\hline $\mathrm{X} 1 * \mathrm{M} 3$ & & & & & & & 39.928(8.056E + 16) & $.448(.641)$ \\
\hline $\mathrm{X} 2 * \mathrm{M} 3$ & & & & & & & $-21.075(.000)$ & $.463(.641)$ \\
\hline $\mathrm{X} 3^{*} \mathrm{M} 3$ & & & & & & & 19.695(357697811) & $1.186(.231)$ \\
\hline$-2 \mathrm{LL}$ & $73.657^{* * *}$ & $718.859^{* * *}$ & $70.790^{* * *}$ & $727.93^{* *}$ & $70.389^{* * *}$ & $723.009^{* * *}$ & $71.440^{* * *}$ & $733.2^{*}$ \\
\hline$N R^{2}$ & .411 & .069 & .446 & .047 & .451 & .059 & .439 & .035 \\
\hline $\mathrm{HL}$ & .539 & .936 & .701 & .334 & .508 & .483 & .530 & .517 \\
\hline
\end{tabular}


test. An increase of one unit $(\mathrm{X} 1, \beta=2.093)$ in the internal $\mathrm{R} \& \mathrm{D}$ activities is linked to an8.106-fold increase in the odds ratio, which refers to the probability of product innovation versus no product innovation (1-p (Y)). A one-unit increase in external $R \& D$ activities $(X 3, \beta=2.643)$ leads to a 14.052 -fold increase in the odds ratio. Thus, it is found that a one-unit increase in external $R \& D$ has a more significant effect on product innovation than does a one-unit increment in internal R\&D.

Second, in the case of SMEs, internal R\&D activities (X1), direct financial support (M1), and indirect support to provide innovation opportunity (M2) are valid at the level of $P$ $<.01$. The odds ratio of internal R\&D activities of SMEs $(X 1, \beta=0.667)$ is 1.948. For SMEs, a one-unit increase in direct financial support (M1, $\beta=0.657)$ from the government led to a 1.93-fold increase in the odds ratio of product innovation performance. The odds ratio of government support programs that indirectly provide innovation opportunity (M2, $\beta=-0.807)$ is 0.446 . Thus, it seems that the probability of product innovation compared to no product innovation decreases $55.4 \%$. Proceeding from this fact, financial support from government support programs has a positive impact on service-product innovation performance, whereas support to provide innovation opportunity does not.

The findings are summarized as follows: First, <Hypothesis $1>$ can be adopted. $<$ Hypothesis $1-1>$ is partially adopted because internal R\&D activities and external $R \& D$ activities have a significant impact on service-product innovation performance in the case of large firms. Also, the internal R\&D activities of SMEs were confirmed to have an impact on product innovation performance, so $<$ Hypothesis $2>$ can be adopted. When large firms received government support, the effect seems to be not valid, and so $<$ Hypothesis 2-1> is not adopted. However, when the government provides financial support and innovation opportunities to SMEs, it has an impact on product innovation, so $<$ Hypothesis $2-2>$ is partially adopted.

(2) Moderating Effect of Government Support Programs on the Relationship between R\&D Activities and Service-Product Innovation Performance (Hypothesis 3)

The model is found to be persuasive because the value of -2LL was smaller in the second, third, and fourth stages, including the moderating effects, than in the first stage, excluding the moderating effects.

The regression coefficients value of interaction term, an important factor used to analyze the moderating effects of government support programs, is not valid. Only the interaction predictor between internal $R \& D$ of SMEs and indirect support to provide innovation opportunity is deemed valid $(\beta=1.207, p<.05)$. This means 3.342 -fold increase in the odds ratio of the probability of service-product innovation performance results from a one-unit increase in the interaction predictor between internal R\&D activities (X1) and indirect support providing innovation opportunity (M2). In other words, indirect government support providing innovation opportunity strengthens the positive effects of the impact of internal $\mathrm{R} \& \mathrm{D}$ activities $(\mathrm{X} 1, \beta=.375, p<.1)$ on service-product innovation performance.

All this considered, $<$ Hypothesis $3>$ is partially adopted, and $<$ Hypothesis $3-2>$ is partially adopted as well because it was confirmed that when SMEs use government support programs that indirectly provide innovation opportunities, the impact of their $R \& D$ activities on service product innovation performance is strengthened. 


\section{Conclusion}

This study analyzed the impact of companies' R\&D activities and government support program on service-product innovation performance as well as the moderating effects of government support program. The following conclusions are drawn. First, R\&D activities are needed for service innovation. Generally, the service industry, a non-technical industry, has been focused on developing new service products and processes that combine the technologies and products developed in other industries. However, according to the results of the analysis, internal and external R\&D activities were a major factor in releasing and improving new service products in the case of both large firms and SMEs. In particular, large corporations had a greater influence from external R\&D than did SMEs. This can be seen as are reflection of the flow of innovation development, whereby certain environments are considered worthy of such leverage of external resources and cooperation including open innovation.

External R\&D activities of SMEs did not affect service-product innovation. The result may be caused by the fact that the proportion of external R\&D activities for SMEs is very low, and thus it was difficult to predict its effect. It can be assumed in advance that the $R \& D$ capability of SMEs is also low compared to that of large enterprises. For SMEs, it is necessary to make voluntary efforts to enhance the external R\&D activities beyond the internal R\&D activities, and the government's policy support is required as well. The effects of government innovation support programs are constantly verified. Therefore, it is necessary to provide different government support programs based on company size. In Korea, there are various institutions related to the innovation support system. However, as is shown in the above results, there seems to have never been in-depth discussion about policy improvements geared toward operating system-specific status and situation.

There are different types of government support schemes affecting service production innovation that have varying effects. The effects of direct financial support can be expected to address the innovation-related difficulties of SMEs. Likewise, it is not expected to be effective to consider institutions uniformly, without respect to industry characteristics, legal standards, and innovation capability. If the development of technology innovation support programs and evaluation and feedback on that form a virtuous cycle, a synergistic effect would be expected between corporation R\&D activities and government support programs.

Despite the aforementioned implications, this study has the following limitations. First, even though service innovation performance can be classified into different types, this study analyzed it in terms of product innovation, just as has been done for the manufacturing industry, in order to obtain survey data on innovation performance. The reliability of this approach is high because the innovative performance measures are borrowed; however, this study may be limited in that it does not reflect a new perspective on the scope and type of services. Second, there are limits to the type of government support schemes. This study classified government support programs into direct financial support, indirect support that provides innovation opportunity, and indirect support to diffuse the results of innovation, based on the standard questionnaire for the KIS data. This cannot cover all of the various support programs. More specific policy-related implications can be derived in future studies of innovation performance that explore more detailed characteristics of the service industry. Thus, additional study needs to be carried out with data based on a questionnaire survey targeting staffs in the service sector. 


\section{Author details}

The Korean Federation of Science and Technology Societies, 22, 7GIL, Teheran-Ro, gangnam-GU 135-703, Seoul, South Korea. ${ }^{2}$ Gyeonggi Institutes of Science and Technology Promotion, 1 Hyoowon-Ro, Padal-gu, Suwon City, Gyeonggi Province 16444, Republick of KOREA. ${ }^{3}$ Program in Science and Technology Studies, Korea University, Seoul, South Korea.

Received: 27 November 2015 Accepted: 26 January 2016

Published online: 17 February 2016

\section{References}

Aldrich, JH, \& Nelson, FD (1986). Linear Probability, Logit and Probit Models (3rd edition). Beverly Hills, CA: Sage Publications. Brown, S, \& Eisenhardt, K (1995). Product development; past research, present findings and future directions. The Academy of Management Review, 20(2), 343-378.

Cainelli, G, Evangelista, R, \& Savona, M (2004). The impact of innovation on economic performance in services. The Service Industries Journal, 24(1), 116-130

Cerulli, G (2008). Evaluating the Effect of Public Subsidies on firm R\&D activity: an Application to Italy Using the Community Innovation Survey, CERIS Working Paper from Institute for Economic Research on Firms and Growth - Moncalieri (TO).

Cohen, W (1995). Empirical Studies of Innovative Activities. in P. Stoneman (ed.). Handbook of the Economics of Innovation and Technological Change. Oxford UK: Blackwell.

Cohen, WM, \& Klepper, S (1996). A Reprise of Size and R\&D. The Economic Journal, 106(437), 925-951.

Czarnitzki, D, Hussinger, K, (2004). "The Link between R\&D Subsidies, R\&D Spending and Technological Performance", ZEW - Centre for European Economic Research Discussion Paper No. 04-056.

Dinopoulos E, Thompson P, (1998). "Schumpeterian growth without scale effects", Journal of Economic Growth, 3,313-335.

Djellal, F, \& Gallouj, F (1999). Services and the search for relevant innovation indicators: A review of national and international surveys. Science and Public Policy, 26(4), 218-232.

Djellal, F, \& Gallou, F (2000). Patterns of innovation organization in service firms: postal survey results and theoretical models. Science and Public Policy, 28(1), 57-67.

Drejer, I (2004). Identifying innovation in surveys of services: a Schumpeterian perspective. Research Policy, 33(3), 551-562.

Edwards M, and Croker M., Major Trends and Issues. OECD Proceedings of Workshop on Innovation and Productivity in Services (pp. 7-15). OECD, Paris, 2001.

Elche, D, \& González, MÁ (2008). Influence of innovation on performance: Analysis of Spanish service firms. The Service Industries Journal, 28(10), 83-99.

Fumio, K, \& Shibata, T (2015). Demand articulation in the open-innovation Paradigm. Journal of Open Innovation: Technology, Market, and Complexity, 1(1), 1-24.

Geroski P.A., Market Structure, Corporate Performance and Innovative Activity, Oxford, Oxford University Press, 1994

Hall, LA, \& Bagchi-Sen, S (2002). A Study of R\&D, Innovation, and Business Performance in the Canadian Biotechnology Industry. Technovation, 22(4), 231-244.

Hipp, C, \& Grupp, H (2005). Innovation in the Service Sector: The Demand for Service-Specific Innovation Measurement Concepts and Typologies. Research Policy, 34(4), 517-535.

Hood, CC (1986). The Tools of Government: Public Policy and Politics, Chatham House Publishers, United States.

Howells, J, \& Tether, B (2004). Innovation in Services: Issues at Stake and Trends. Commission of the European Communities: Brussels.

Jongkook, S, \& Hyukjoon, K (2009). The Effectiveness of Fiscal Policies for R\&D Investment. Journal Of Technology Innovation, 6, 1-18.

JinHyo Joseph, Y (2015). How do we conquer the growth limits of capitalism? Schumpeterian Dynamics of Open Innovation. Journal of Open Innovation: Technology, Market, and Complexity, 1(17), 1-20.

Kang SM (2013) "The Impact of Korean SMEs' R\&D Effort on Innovation-The Moderating Effects of Government Policy Supports". Management and Information Systems Review, 32(1).

KangKi, H, \& Kang, J (2014). Do External Knowledge Sourcing Modes Matter for Service Innovation? Empirical Evidence from South Korean Service Firm. The Journal of Product Innovation Management, 31(1), 176-191.

Keizer, JA, Lieuwe, D, \& Johannes, IM (2002). Halman. Explaining Innovative Efforts of SMEs: An Exploratory Survey Among SMEs in the Mechanical and Electrical Engineering Sector in the Netherlands. Technovation, 22(1), 1-13.

Ki-Wan Kim, Youjin Youn, An Analysis of Patterns and Determinats of Service Companies' Innovation in Korea, KDI, 2010

Kim, T, \& Do, S (2004) Meta-Evaluation of The Outcomes of The Government Support Policy for The Venture Business. The journal of Korean Association For Policy Analysis And Evaluation, 14(3): 23-50.

Kim, Ka (2014). Korea's Corporate RTI Support System: Current Status and Policy Issues. Korean Journal of Local Government \& Administration Studies, 28(2), 215-238.

Lee, J-H, \& SeoHwan, J (2013). The relationship between technological innovation activities and firm size in the service industry: Schumpeterian Hypothesis. Journal Of Technology Innovation, 21, 20.

Lee Do hyung. Korea's Corporate RTI Support System : Current Status and Policy Issues. KISTEP; 2011.

Lin, BW, Li, PC, \& Chen, JS (2006). "Social capital, capabilities, and entrepreneurial strategies: A study of Taiwanese high-tech new ventures". Technological Forecasting ve Social Change, 73, 168-181.

McDonnell, LM, Elmore, RF (1987). Alternative policy instruments, Santa Monica, CA, RAND Corporation.

Neter J, Wasserman W \& Kutner, MH (1985). Applied linear statistical models. Homewood. IL: Irwin.

OECD, Oslo Manual: Guidelines for Collecting and Interpreting Innovation Data, Paris: OECD, 2005.

Rogers, M (2004) "Networks, Firm Size and Innovation". Small Business Economics, 22, 141-153

Romer, Paul M (1990). "Endogenous Technological Change," Journal of Polit-ical Economy, 96, S71-S102.

Rouvinen, P (2002). Characteristics of product and process innovators: some evidence from the Finnish innovation survey. Applied Economics Letters, 9(9), 575-580. 
Ryu YS, Choi SO (2011). "The success factor of university industry cooperation with government supporting program", Korean Public Management Review, 25(4).

Scherer, FM (1965). "Firm Size, Market Structure, Opportunity, and the Output of Patented Innovations", American Economic Review, 55, 2097-1125.

Scherer, FM, \& Ross, D (1990). Industrial Market Structure and Economic Performance. Chicago: Rand McNally.

Schneider, A, Ingram J (1990). "Behavioral Assumption of Policy Tools", The Journal of Politics, 52, (2), 510-529.

Schumpeter, J (1942). Capitalism, Socialism and Democracy. New Yock: harper Lin, B. W., Y.

Shefer, D, \& Frenkel, A (1998). Local Milieu and Innovation: Some Empirical Results. Annals of Regional Science, 32, 185-200.

Sung, T (2003). A Firm Size - Innovative Activity Relationship: An Empirical Study of the Korean Manufacturing Industry. The Korean Small Business Review, 25(2), 305-325.

Swapan Kumar, P, \& Krishna, W (2015). Globalization of R\&D and open innovation: linkages of foreign R\&D centers in India. Journal of Open Innovation: Technology, Market, and Complexity, 1(7), 1-24.

Van Riel, ACR, Lemmink, J, \& Ouwersloot, H (2004). High-technology service innovation success: A decision-making perspective. The Journal of Product Innovation Management, 21(5), 348-359.

Vedung, E (2005). Policy Instruments: Typologies and Theories. In Carrots, Sticks and Sermons: Policy Instruments and Their Evaluation edited by Marie Louise Bemelmans-Videc, Ray C. New Brunswick: Rist, and Evert Vedung.

Hongrim, Y, \& Sungjun, P (2006). A Study on the Performance Analysis of Supporting Policy for SMEs R\&D: Focused on the Industry-University-Institute Consortium Program. Journal of Korean Association of Governmental Studies, 19(1), 171-195.

Submit your manuscript to a SpringerOpen ${ }^{\circ}$ journal and benefit from:

- Convenient online submission

- Rigorous peer review

- Immediate publication on acceptance

- Open access: articles freely available online

- High visibility within the field

- Retaining the copyright to your article

Submit your next manuscript at $>$ springeropen.com 